Michael Essig, Bundeswehr University Munich, Chair for Materials Management, Distribution and Logistics

Andreas H. Glas, Bundeswehr University Munich, Research Centre for Law and Management of Public Procurement

Simon Mondry, German Bundeswehr

\title{
A COST INCREASE ANALYSIS OF WEAPON SYSTEMS USING THE PAACHE INDEX: CASES FROM THE GERMAN BUNDESWEHR
}

\begin{abstract}
The media and the public often make claims regarding the excessive cost increases in the development and production of major weapon systems such as fighter planes, submarines or tanks. The purpose of this research is in assessing the cost increase of such weapon systems during their procurement periods with the help of the Paasche price index. In contrast to other approaches, which focus upon either the specific situations of single weapon systems or cost increases relative to planned budgets, we compare several projects of military services and their cost increases over time to reveal generalisable trends.

For this purpose, we used a framework model that allows for performance and cost comparisons. This paper primarily emphasises the cost perspective by calculating a Paasche index for each chosen project. As a background case for our analysis, we have used the acquisition projects for major weapon systems in Germany. However, the framework model that this study employs is universally applicable.

In contrast to the public perception of cost increases, we could not find any clear trend that would indicate that modern weapon systems have a significantly higher (or lower) cost increase than was the case for projects several decades before. To give brief insight into the empirical findings, the cost increase ratios of the Starfighter and Eurofighter jets have the same level, while cost increase ratios of other weapon systems (APC tanks, submarines) differ significantly (to the worse and to the better) over time. Our findings imply that there is no general trend that today the costs for weapon systems increase morelless than some decades ago. This paper calculates data only from the regarded seven cases therefore we could not question the causes for this observation on basis of our sample. However, it appears that, within a specific service or a specific vehicle type (tank, fighter jet, ship/boat), cost increases may be similar over time.
\end{abstract}

\section{Keywords}

Defence procurement, weapon system, cost increase, Paasche index

\section{Introduction}

Although many national armed forces, at least in Europe, have recently reduced their sizes in personnel and equipment, their military tasks have increased, with a wide range of possible mission scenarios, including wars against terrorism, fights against piracy, peace enforcement operations, or military observer missions. This challenge is overshadowed by the reality that 
governmental spending will diminish even more in the near future, and defence is unlikely to be immune from these cutbacks (Tatham and Worrell 2010; Taylor and Tatham 2008). Current estimates suggest that the German Ministry of Defence will be required to reduce its budget by $€ 8.3$ billion over the period 2011-2014 (Klos 2011). In the United Kingdom, a budget reduction of a minimum of 10-15 per cent in real terms is required over the period 2010-2016 (RUSI 2009).

The challenge to do more with less leads to the imperative to seek avenues for potential savings. The efforts in this direction focused for many years on reducing the total costs of ownership / total lifecycle costs (Ellram and Siferd 1998). In the defence sector, savings initiatives attempted to optimise the total capabilities and costs for a weapon system (Tatham and Worrell 2010; MoD 1998). The rationale underlying this is the combined economic analysis of the capital purchase of new equipment and its support and maintenance during its usage phase. In fact, higher initial quality and hence a higher capital cost could be accepted, if, in return, the resultant additional costs over the lifecycle would decrease (and vice versa). The orientation of savings efforts on total cost reduction led to the development of numerous optimisation programmes and initiatives, such as performance-based logistics, smart acquisition, and availability- or outcome-based contracting (Geary and Vitasek 2008; DoD 2001; Hypko et al. 2010; Ng and Nudurupati 2010).

However, there is a two-stage approach to any proposed defence acquisition project, and these two stages combine to ensure project performance. These stages consist of the initial phase, which involves the choice and procurement of capabilities, followed by the setup of the performance metrics to be used over the life cycles of the capabilities (Barber and Parsons 2009). Although we completely agree with the necessity of the aforementioned total cost perspective, the approach of Barber and Parsons reopens questions regarding the potential perceptions of the capital costs of the initial purchase phase.

In the public's perception, the costs to buy new defence equipment continuously increase. Striking examples of costly defence equipment include the European transporter airplane A400M ( € 190 million per aircraft) or the future aircraft carrier in the UK (with costs of over $€ 3$ billion), which are broadly discussed by the media and public (Schwarz 2003; Bellmann et al. 2011; Schank 2005). These high costs occur despite the fact that technical performance objectives are often not reached in early phases of the new equipment's inservice time. To a certain extent, the cost overruns that occur could be explained by military decisions to reduce fleet sizes but preserve the same equipment usage profiles, which 
significantly increases maintenance costs of highly specialised equipment. The German air force, for example, has 14 fleets of military jets or helicopters that contain fewer than 25 single items each.

Given the background discussed above, the objective of this paper is to develop a holistic and conceptual model for the comparison of different weapon systems. Although the model also allows for consideration of the differences in the weapon system performances, this particular paper focuses upon the cost aspect of the model's framework. In this study, we adapt the model to the particular context of German weapon systems.

Research on this topic is still scarce because much of the data on costs for major weapon systems are confidential and unreliable. To the best of our knowledge, there are very few studies addressing this subject. Thus, we first seek to build a general framework of a model for the cost and performance analysis of different weapon systems. After this introduction, we will present a brief summary of the literature and practice regarding cost developments in the defence sector. We will then develop the framework model, after which we will present the empirical data from seven projects. The findings from these projects and our conclusions will summarise the paper and provide further recommendations for research and practice.

\section{A review of the defence acquisition of major weapon systems and the study methodology}

Major defence acquisition programmes account for a large share of the total defence budget authority (Ferrara 1996). Air force planes, navy ships or army tanks are examples of complex and costly acquisition programmes of major weapon systems. To respond to the increased likelihood of unconventional threats and asymmetrical warfare, military requirements have been shifting in recent decades. The major weapon systems are no longer as specialised as an attack helicopter or a main battle tank, but rather are multi-role systems and a type of systems integrator for the overall force (Rogers and Birmingham 2004).

The increased complexity of defence acquisitions is not only due to changed military requirements; rather, rapid technology changes that cause premature obsolescence have become particularly problematic for very large systems with acquisition life cycles spanning a long period of time (Dillard 2005). Also, the roles and responsibilities in military-industry cooperation dynamics have shifted and produced new coordination mechanisms. Large multiyear cost-plus contracts are gone, replaced by a new environment of performance-based contracts and milestone development designed to protect the military budget from being 
overrun (Rogers and Birmingham 2004). However, concurrently, close military-industry cooperation and performance-based contracts have introduced new dependencies and risks as well as a high level of uncertainty into the programme management aspect of the acquisition of major weapon systems.

An analysis of 197 defence programmes in the US from 1960 to 1990 that focused on the programmes' capital costs revealed that the average cost growth of these programmes was 20 per cent and did not change significantly for 30 years (Drezner et al. 1993). Another study reviewed 269 defence contracts in the US and reached the same conclusions (Christensen et al. 1999). Despite the implementation of more than two dozen regulatory and administration initiatives, there has been no substantial improvement in the cost performance of defence programmes for more than 30 years. Even worse, Christensen et al. (1999) identified that after one reform, the average cost overrun of defence acquisition projects increased.

Another study identifies a clear, even linear, trend of increasing production costs per kilogram of basic mass empty of combat aircrafts, main battle tanks, attack helicopters and other weapon systems (Pugh 2007). As a result, that study identifies a steady unit cost escalation, which continues apace. Similar to our approach that study does not explore the causes for cost increases, but question the results and their consequences. It states that one consequence is to compare cost increase tendencies of different weapon systems (e.g. aircraft, helicopter, tank, unmanned aerial vehicle etc.) and to think about their future affordability and relevance in warfare (Pugh 2007). Almost in the same direction argues another study, which identifies progressively higher costs for successive weapon systems and fathoms their causes in relation to the military threat, productivity or technology developments, and life-cycle costs (Kirkpatrick 2004). Concerning the linear or even progressive cost development of those studies, a ciritical point is that it is quite obvious that the basic mass empty of a modern weapon system is more expensive than its predecessors, e.g. the Eurofighter Typhoon, is more expensive than the Tornado, the Starfighter, the Messerschmitt 109, or even the Rumpler Taube aircraft. But it is quite unclear, which cost increase ratio (cost overrun) each weapon system had and if those ratios could be compared with consequences for the future.

One explanation for cost overruns might be that major weapon systems are technologically advanced products, often designed to achieve performance levels never before realised (Ferrara 1996). The resulting high levels of uncertainty and technical risk demand skilled and intelligent management of cost and performance because unplanned cost increases in defence 
procurements can escalate to staggering amounts and can adversely affect resource allocation decisions, especially when defence budgets are decreasing (Christensen et al. 1999).

Surprisingly, most studies measured the cost overruns (CO) of single projects simply by subtracting final budgets from final costs (a.o. of Drezner et al. 2003; Christensen et al. 1999). The calculation of an average cost overrun has been made by dividing the sum of cost overrun percentages over all regarded projects by the number of projects.

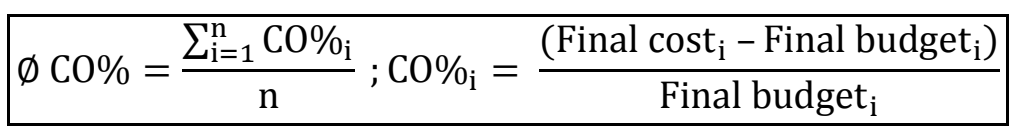

Both of these studies could provide an average cost overrun for the contracts that they considered (and even explored their causes). However, this methodology does not compare the cost increase of different weapon systems over time.

Therefore, in this study, we use a statistical methodology adopted from market basket comparisons. Prices, in general, do not move up and down in perfect unison. They move differently for different items; thus, an increase or decrease in overall price levels cannot be identified by a simple glance. To calculate an average of these divergent movements, index numbers are used. These index numbers indicate the average percentage change of prices from one point of time to another. A commonly accepted approach to measuring changes in the general price level is the "Paasche index". Similarly to other indices (such as the "Laspeyres Index"), the Paasche index is evaluated as a weighted average of price ratios. Indices have long had a particular significance for practical and theoretical investigations of cost-related issues and are used to support various calculations, such as those of the cost of living over time (Fisher 1922; Siegel 1941; Selvanathan 1990).

The measure is defined as follows: $x_{i}^{0}$ is a set of quantities associated with the number $i$ of items, and $\mathrm{P}_{\mathrm{i}}^{0}$ is a corresponding set of prices for a chosen base year. $\mathrm{P}_{\mathrm{i}}^{\mathrm{t}}$ and $\mathrm{x}_{\mathrm{i}}^{\mathrm{t}}$ are the values for the same number of items at another time. The Paasche index for $\mathrm{P}_{\mathrm{i}}^{\mathrm{t}}$ at $\mathrm{t}_{0}$ is calculated as follows and provides the ratio of price development over time (Siegel 1941):

$$
\mathrm{I}_{\mathrm{pa}}^{\mathrm{p}}=\frac{\sum_{\mathrm{i}=1}^{\mathrm{n}} \mathrm{x}_{\mathrm{i}}^{\mathrm{t}} \times \mathrm{P}_{\mathrm{i}}^{\mathrm{t}}}{\sum_{\mathrm{i}=1}^{\mathrm{n}} \mathrm{x}_{\mathrm{i}}^{\mathrm{t}} \times \mathrm{P}_{\mathrm{i}}^{0}}
$$


We embed the Paasche index, which is used as a new approach for analysing the cost development of major weapon systems, into an analysis framework to provide a setup which allows for cost comparison of different acquisition projects in the defence sector.

\section{Analysis framework}

The comparison of armament prices requires not only a mathematical formula to calculate prices and cost overruns but also a methodical, academic basis for the collection and evaluation of price data. Economics provides multiple tools for addressing these types of issues; although it is only one of the tools available, perhaps the most famous of these techniques is benchmarking. The objective of benchmarking is to improve economic processes, products and services by measuring, evaluating, and implementing economic data and attributes that are attained by inter- and intra-organisational comparisons (Raymond 2008; Lau et al. 2001; Camp 1989). The literature provides a method for applying benchmarking to projects by dividing it into several phases, which can increase the clarity, comprehensibility and adaptability of this tool. In particular, although benchmarking is a continuous and systematic process, it is often structured into the following stages: planning, data acquisition, data evaluation and implementation (Maire 2002; Böhnert 1999; Keller 1996). The possibility of adopting benchmarking by concentrating on the elements that are relevant for defence procurement issues increases the attractiveness of this approach for the present analysis. Although the public sector has been the subject of several benchmarking studies (Magd and Curry 2003; Tavana 2004; Triantafillou 2007; Vagnoni and Maran 2008), benchmarking has only rarely been applied to defence in particular (Tavana et al. 2009). In this paper, we use elements of the benchmarking methodology as a foundation for comparing different elements of defence, addressing, in particular, types of military equipment over time and with respect to the service using the equipment (Figure 1).

The analysis framework is a type of assortment profile in form of a three-dimensional model with the following axes: period of procurement, military user, and defence material (ordnance) category. Accordingly to the benchmarking idea, this paper compares different weapon systems (vehicles) of different services in different periods with each other in respect to their cost increase measured with the Paasche index. 


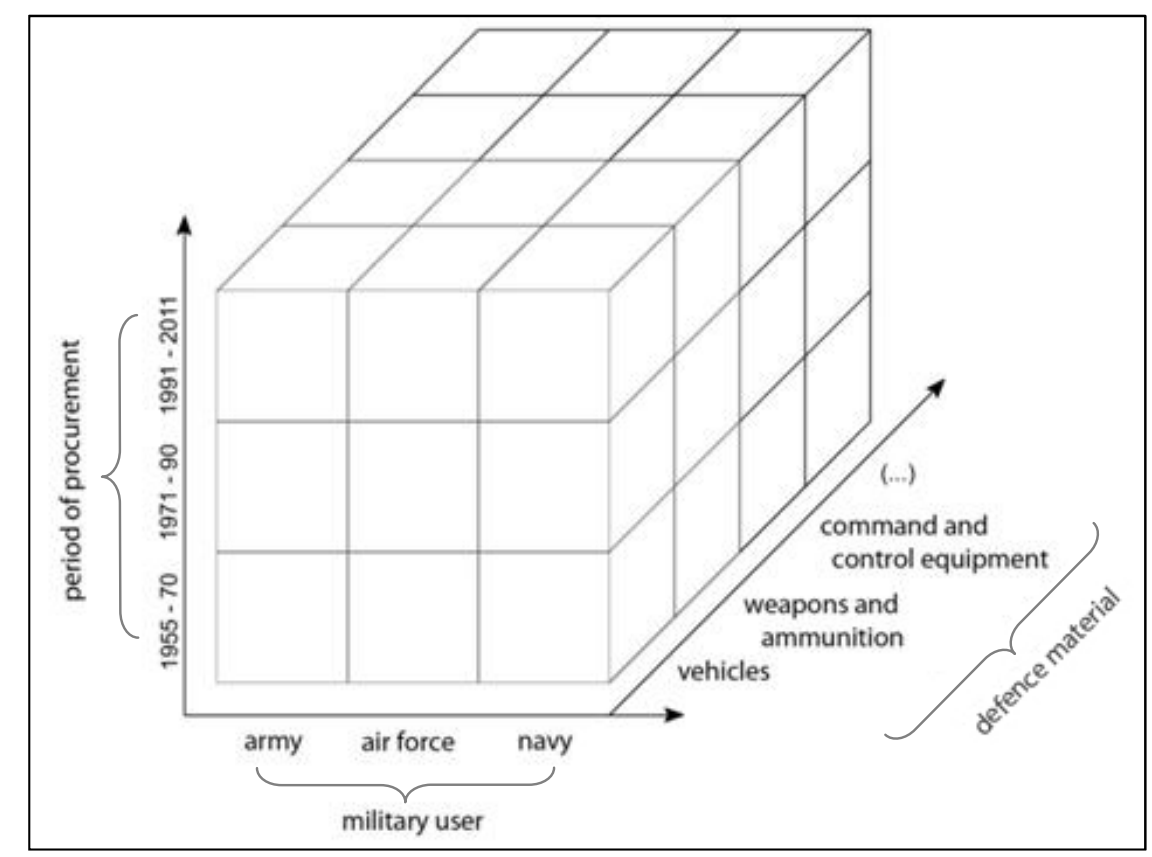

\section{Figure 1: The assortment profile of the analysis framework}

The development of the framework was based upon typical considerations of benchmarking in (public or defence) procurement. We followed the four phases of (1) general conception, (2) planning of analysis, (3) measurement, and (4) explanation of results (according to similar approaches: Dresen 1997; Bogan and English 1994). We concentrate upon the model's descriptive level. The documentation and evaluation of cost increases of defence procurement objects (in this case, German Bundeswehr material) is the core of our analysis. The identification of the causes (explanation of the results) that led to these cost increases is not the topic of this paper, primarily because there are a number of conceptual complications involving military expenditures and their interrelation with politics and military strategy (Brzoska 1995).

Our analysis starts with the first step, general conception, in which the intention and methodology of the analysis is defined. The objective of this step is to document the cost increases of military equipment and to relate these to data that apply to the equipment's performance, procurement and service life. Based on this information, it is possible to compare and benchmark the objects among themselves, allowing for a statement to be made regarding their cost development.

The second step, planning of analysis, identifies the analysis objects via funnel assortment. The term defence material is very comprehensive and thus had to be constrained to enable an adequate analysis. In particular, for this case study, we decided to only analyse German 
Bundeswehr vehicles, although the chosen method provides the opportunity to analyse all kinds of defence material, e.g., weapons, ammunitions, or command and control equipment. Initially, we did not want to focus only on costs, and thus, we defined four pillars of information regarding one analysis object: capital costs, system costs, in-service lifetime and performance information. These four terms could represent four analysis levels, which act as the theoretical basis for developing operating figures. Then, the phase of collecting data and information was initiated and a profile was evaluated for every analysis object. These evaluations regarding costs formed the core of the research presented here.

In combination with each single analysis object, the analysis framework in the form of the three-dimensional assortment profile could be filled. The allocation of objects into three different time clusters offers the possibility of analysing the defence material of each military user with reference to their procurement period. The observed time clusters consist of the following periods: 1955 to 1970 ; 1971 to 1990; and 1991 to 2011. At the end of each time period, the acquisition strategy for military equipment in Germany had been restructured. This could but must not result in similar cost increase ratios for each time cluster.

A second possible research opportunity would be to compare all analysis objects in relation to their military users. The three possible German users of military equipment are the separate military services of the army, navy and air force. The last alternative method for comparing the objects would be in relation to the defence material category from which they arise, e.g. vehicles and command and control equipment. The latter one is not part of this paper.

The term defence material is very extensive. In its broadest sense, it describes all of the material that is used by the military. It is possible to generate greater specification by dividing defence materials into ordnance of weapons and gear, but even these classifications are too abstract to adequately differentiate military equipment. This study divides defence material into the following categories: vehicles; weapons and ammunition; and command and control equipment. These categories can obviously be expanded, if desired. However, this paper limits its scope to the analysis of military vehicles, such as armoured personal carriers, tactical aircrafts and submarines. Therefore, we focused on cost increases of major weapon systems (similarly to Arena et al. 2006).

Whereas the data with reference to procurement, service life and performance level are processed descriptively, a comparison of cost data requires the development of operating figures. Price indices, which are used to calculate market baskets of commodities, can 
function as the desired operating figures. Initially, the data used for calculations in this study are standardised by conversion to prices in Euros. If there is no standardisation, the price data that arise from different years or centuries cannot be accurately compared. Thus, the price data must be adjusted to the price levels of a base year, which was 2010 for this particular study. To do so, an individual average rate of inflation is calculated for each year.

$$
\overline{\mathrm{i}}_{[\mathrm{a}, 2010]}=\frac{1}{\mathrm{n}} \sum_{\mathrm{j}=1}^{\mathrm{n}} \mathrm{i}_{\mathrm{j}}
$$

To calculate the adjusted price for the year 2010, the average rates of inflation are used in the following compound interest formula.

$$
\mathrm{P}^{2010}=\mathrm{P}^{\mathrm{a}} \times\left(1+\overline{\mathrm{i}}_{[\mathrm{a}, 2010]}\right)^{\mathrm{n}}
$$

This calculation permits all prices to be standardised and subsequently used for any further calculation of price indices. This research uses the Paasche index to determine the figures used for standardisation (Allen 2008). This index compares the prices and the quantities of goods of a base year with those of a comparative year to gain an average cost increase figure. It is only one method of showing the price increase of baskets of commodities. A second, similar method is the Laspeyres index. The difference between these two methods lies in the usage of the quantity of goods. Whereas the Laspeyres index uses the quantity from the base year $\mathrm{X}_{0}$, the Paasche index uses the quantity from the comparative year $\mathrm{X}_{1}$. In this case, the quantitative data from the comparative year are more reliable (Fisher 1922; Siegel 1941; Selvanathan 1990).

$$
\mathrm{I}_{\mathrm{pa}}^{\mathrm{p}}=\frac{\sum_{\mathrm{i}=1}^{\mathrm{n}} \mathrm{x}_{\mathrm{i}}^{\mathrm{t}} \times \mathrm{P}_{\mathrm{i}}^{\mathrm{t}}}{\sum_{\mathrm{i}=1}^{\mathrm{n}} \mathrm{x}_{\mathrm{i}}^{\mathrm{t}} \times \mathrm{P}_{\mathrm{i}}^{0}}
$$

The difference between the calculations of these indices and the calculations underlying this research is in the amount of goods considered. Although the indices require several goods to demonstrate the price changes of a basket of commodities, this research should compare the different prices over time for only one military vehicle. Therefore, a sum of prices is not needed. To match the requirements of this research, the formula has been simplified.

$$
\mathrm{I}_{\mathrm{pa}}^{\mathrm{p}}=\frac{\mathrm{x}^{\mathrm{t}} \times \mathrm{P}^{\mathrm{t}}}{\mathrm{x}^{\mathrm{t}} \times \mathrm{P}^{0}}
$$


The Paasche index produces a value between 0 and $\infty$. Values that are higher than 1 indicate a price increase, whereas values lower than 1 indicate a price decrease (Pinnekamp and Siegmann 2001).

After defining the operative figures, this analysis continues with calculating the indices for each analysis object from the gathered data. As we had only limited access to real contract prices and their development, we decided to focus only on publicly available data. One reason for this decision is that such data are also the primary source of information for the public and consequently are the data that influence the common perception of cost developments in defence. To analyse the price development of the German Bundeswehr, we utilised a data collection method that concentrated on search engines for the Internet, the German National Library and EBSCO for scientific journals. Obviously, we focused primarily on German data sources. At the end, we used data from literature (Ambos 1980; Blume 2007; Brzoska and Voss 1996; Gaul 2008; Henken, 2003; Hilmes 2006; Johannson 1969; Knight 2002; Kollmer 2002; Liebau 2002; Plate 2005; Rauch and Dinse 1998; Scheibert 1987; Schmidt 1979; Schlotter 1967), statistical and administrational publications (BMVg 2006; Bundesbank 2011; Bundesregierung 2010; Eurostat 2011; Unciatrends 2011; PSM 2010; Luftwaffe 2006, 2007, 2011; Royal Air Force 2002) and even "grey" literature from the press or other media (Behling 2003; IFHS 2010; Spiegel 1992; defense-aerospace.com 2006; Zeit 1991).

The following chapter will present the research findings. It will begin by considering the armoured personal carriers "SPz Puma", "SPz Marder 1" and "SPz HS 30", and will continue by addressing the tactical aircraft "Eurofighter 2000 Typhoon", "MARC Tornado" and "F104 G Starfighter". The chapter finishes with the presentation of the findings concerning the submarine “Type 212 A".

\section{Findings}

The investigation of the chosen military vehicles closes the descriptive portion of the generated model. First, it should be noted that each analysis object must be examined independently. A comparison between the objects is not considered possible before the data for each object are collected and evaluated. The following sections will describe the findings for the armoured personal carrier (APC) Puma and the Eurofighter 2000 Typhoon in detail. The cost development for each of these objects is displayed graphically, whereas the price indices for each are calculated in a stepwise fashion. The findings for the remaining analysis objects are shown without further description. The collection and evaluation of the data 
concerning the remaining objects were conducted using analogous procedures to those employed for the presented cases.

\section{APC Puma}

The APC Puma is a tactical response to the European Union's task force concept developed during the 1990s. This concept demanded the possible global deployment of up to 60,000 men within 60 days and thus justified the need for a new APC. The project was approved by the German Bundestag in the year 2002. The result was a highly adaptable system that can be configured to adapt to various different threats. In particular, an assortment of different protection levels guarantees the safety of the crew, which consists of nine soldiers. By the year 2011, the Bundeswehr planned to procure 405 units of this APC. Figure 2 presents the price development of the unit price and the system price of the APC Puma. Whereas the unit price describes the value of a functional APC without further equipment, the system price indicates the total cost of an APC Puma with e.g., weapon systems, command equipment and crew training. Between the years of 2004 and 2011, the unit price increased continuously from $€ 6.261$ million to $€ 9.258$ million. The first system price information from the year 2002 was estimated at $€ 4.878$ million. Between the years of 2002 and 2011, this price also increased continuously, although the rate of increase was lower after the year 2004, with a 2011 system price estimate of $€ 9.791$ million.

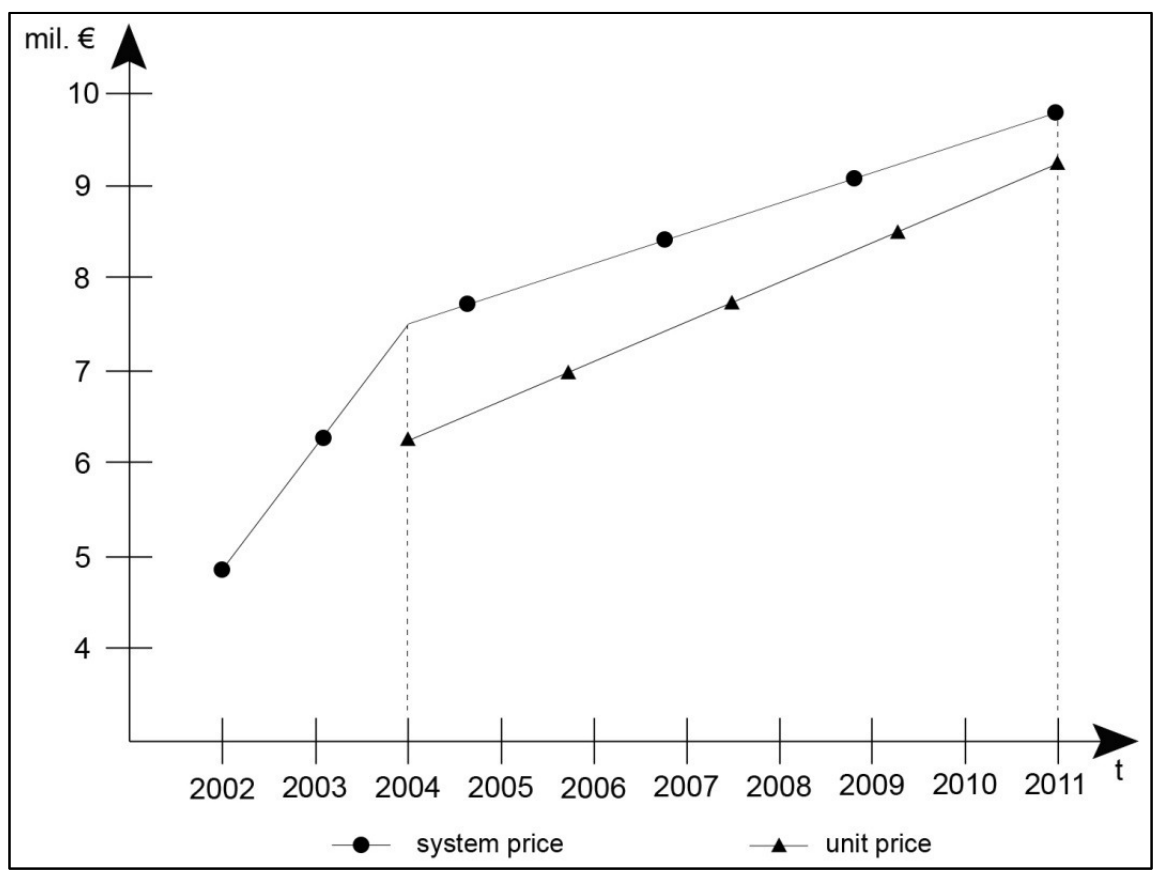

Figure 2: System price and unit price development of the APC Puma 
The calculation of the price indices is initiated by determining the appropriate interest rates to use for standardising the price data to the year 2010. To do so, the unit price from the year 2004 has been inflated by an average annual interest rate of 1.6 per cent, whereas the price from the year 2011 has been deflated at a 2.4 per cent annual interest rate.

$$
\begin{aligned}
& 6.261 \text { mil. } € \times 1.016^{7}=6.997 \text { mil. } € \\
& 9.259 \text { mil. } € \times 1.024^{-1}=9.042 \text { mil. } €
\end{aligned}
$$

These standardised unit prices can now be used to calculate the unit price index. The result shows a unit price index of 1,292 . This calculation complies with a real unit price increase of 29.2 per cent within seven years.

$$
\frac{405 \times 9.042 \text { mil. } €}{405 \times 6.997 \text { mil. } €}=1.292 \rightarrow 129.2 \%(29.2 \%)
$$

The following calculation of the system price index proceeds analogously to the calculation of the unit price index. To permit a better comparison of the two indices, equal periods of time are chosen. Therefore, the standardisation of the system price data proceeds using the same average interest rates from the years 2004 and 2011.

$$
\text { 7.511mil. } € \times 1.016^{7}=8.394 \text { mil. } €
$$

$$
9.791 \text { mil. } € \times 1.024^{-1}=9.562 \text { mil. } €
$$

The result shows a system price increase index of 1,139 , which complies with a price increase of 13,9 per cent within the same period of time.

$$
\frac{405 \times 9.562 \text { mil. } €}{405 \times 8.394 \text { mil. } €}=1.139 \rightarrow 113.9 \%(13.9 \%)
$$

\section{Eurofighter 2000 Typhoon}

Another procurement object for which we have a comparatively detailed data set is the warplane Eurofighter 2000 Typhoon. This project was introduced as an answer to the massive increase of the air fleets of the Warsaw Pact countries and those nations' offensive air doctrines during the eighties (Brzoska and Voss 1996). At first, this warplane was intended to be an adequate interceptor, but later this plan was altered such that the Eurofighter became a 
multirole warplane, able to operate in both interceptor and fighter-bomber roles (Luftwaffe 2007). The first of these planes was introduced to the German air force in 2004.

Seven years before, in the year 1997, the procurement of 180 fighters in total had been agreed to by contract. This delivery was divided into three tranches. The first tranche of 44 machines should have been completely delivered within the year 2006. The second tranche of 68 machines has been contracted in 2004. The third and final tranche was divided into two parts for reasons of financial flexibility. These tranches, $3 \mathrm{a}$ and $3 \mathrm{~b}$, constituted 31 and 37 machines, respectively. Tranche 3a has been contracted in 2009 (IFHS 2010; Knight 2002; Brzoska and Voss 1996).

Figure 3 displays the unit price and system price increases for the Eurofighter 2000 Typhoon project. Whereas the unit price indicates the cost of a functional aircraft, which fulfils the technical requirements of an aircraft, the system price indicates the cost of a fighter aircraft with weapon systems, pilot and crew training, and thus is representative of the total costs of a Eurofighter 2000 Typhoon for the German Luftwaffe. The graphs for these two prices in Figure 3 illustrate the price development for this warplane between the years of 1988 and 2009. Whereas the system price graph indicates the cost development between 1988 and 2007, the unit price graph indicates the cost development between 1994 and 2009. Both graphs reach their gross high in the year 2004.

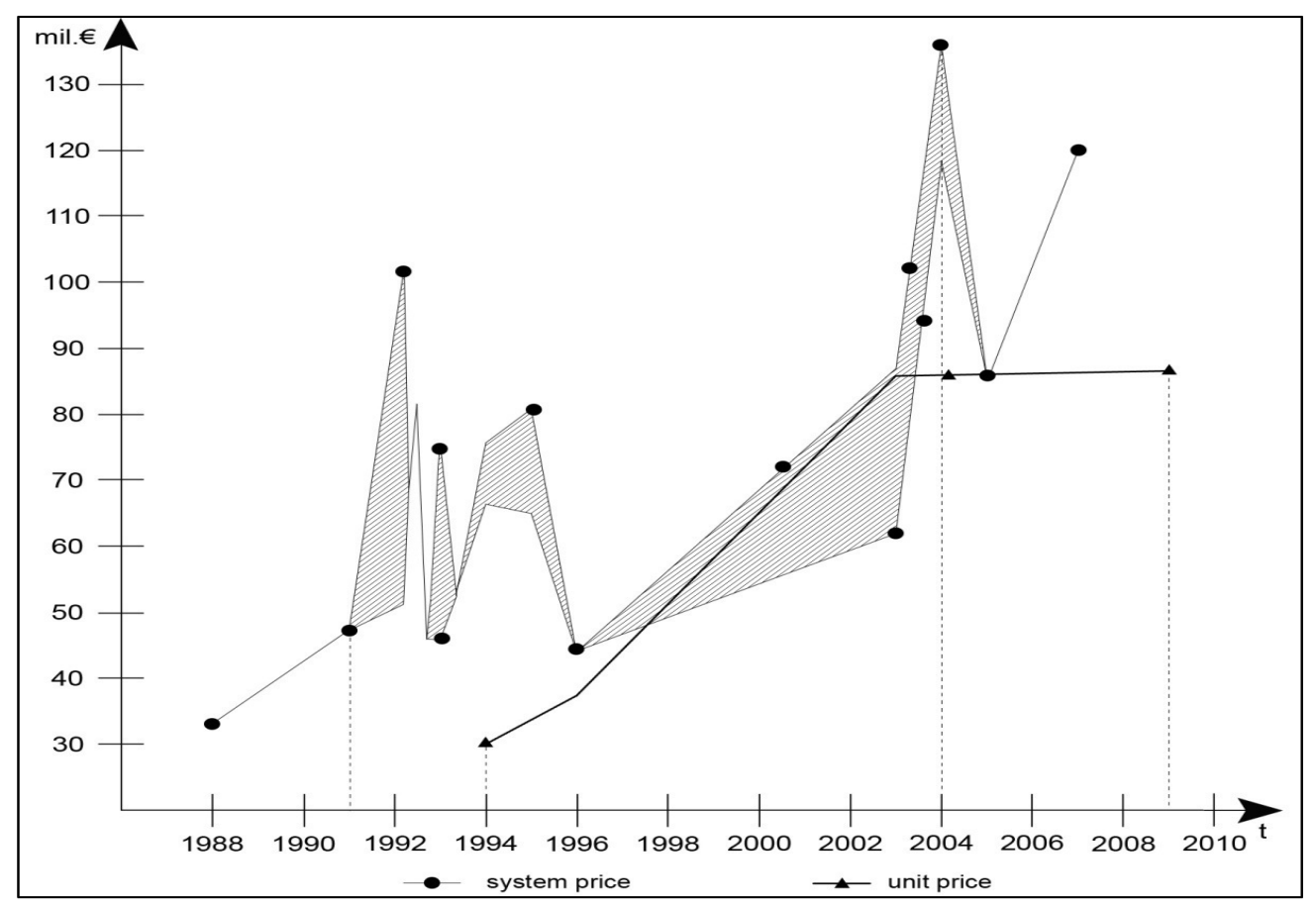

Figure 3: System and unit price development of the Eurofighter 2000 Typhoon 
The different price indices are calculated analogously to the calculations of indices for the APC Puma. The calculation of the unit price index is based on data from the years 1994 and 2009 (Brzoska and Voss 1996; Stauch and Hofmann 2004). These data are standardised with the average interest rates of 0.75 and 1.559 per cent (Eurostat 2011; Bundesbank 2011; Gaul 2008; Unciatrends 2011).

$$
\begin{aligned}
& 86.000 \text { mil. } € \times 1.0075^{2}=87.295 \text { mil. } € \\
& 29.553 \text { mil. } € \times 1.01559^{17}=38.443 \text { mil. } €
\end{aligned}
$$

These standardised unit prices are used to calculate the unit price index. The result shows a unit price index of 2.271. This equates to a unit price increase of 127.1 per cent within 15 years.

$$
\frac{180 \times 87.295 \text { mil. } €}{180 \times 38.443 \text { mil. } €}=2.271 \rightarrow 227.1 \%(127.1 \%)
$$

The calculation of system price index is based on the prices of the years 1991 and 2004 (amongst others: Brzoska and Voss 1996; Henken 2005; Spiegel 1992, etc.) with the average interest rates of 1.6 and 1.99 per cent (Eurostat 2011; Bundesbank 2011; Gaul 2008; Unciatrends 2011). The calculation with the standardised values demonstrates a system price index over 13 years of 2.174 , corresponding to a price increase of 117.4 per cent during that time.

$$
\begin{aligned}
& 136.100 \text { mil. } € \times 1.016^{7}=152.095 \text { mil. } € \\
& 47.167 \text { mil. } € \times 1.0199^{20}=69.950 \text { mil. } € \\
& \frac{180 \times 152.095 \text { mil. } €}{180 \times 69.950 \text { mil. } €}=2.174 \rightarrow 217.4 \%(117.4 \%)
\end{aligned}
$$

The price data from the year 2004 include several different cost estimates. As it is not completely clear which of these values most closely matches the actual price, a second system price index is calculated using the other price for this year (defense-aerospace.com 2006). As a result, it is possible to identify a maximum index and a minimum index.

$$
118.300 \text { mil. } € \times 1.016^{7}=132.203 \text { mil. } €
$$




$$
\frac{180 \times 132.203 \text { mil. } €}{180 \times 69.950 \text { mil. } €}=1.89 \rightarrow 189 \%(89 \%)
$$

The second calculation shows a system price index of 1.89 , which corresponds to a price increase of 89 per cent. This implies that the true system price increase lies somewhere between 89 and 117.4 per cent.

\section{Calculation of the other cases}

The calculation of the unit and system price indices that refer to the other objects analysed was conducted in accordance with the calculations for the APC Puma and the Eurofighter 2000 Typhoon. The two other APCs that were procured by the Bundeswehr during the period studied are the APC HS 30 and the APC Marder 1. The former was introduced to the army in the year 1959. The Bundeswehr procured 2,176 of these systems, which were produced and delivered within six years (Plate 2005; Kollmer 2002). The calculated unit price index lies between 0.968 and 1.963, which corresponds to a price decrease of -3.2 per cent and a price increase of 96.3 per cent. The reason for this broad range is that different unit price estimates were found during the year 1956. Within that one year, the anticipated prices increased from $€$ $76,693.78$ to $€ 127,822$. (Kollmer 2002). As a result, the unit price index changes significantly depending on which of these figures is used for the calculations.

The APC Marder 1 was delivered to the army between 1971 and 1975. In total, 2,136 systems have been procured. The latest version, the APC Marder 1 A5, is still in use and serves the Bundeswehr in Afghanistan (Plate 2005; Hilmes 2006; Blume 2007; Scheibert 1987). The calculation of the unit price index results in a value of 1.064 , which corresponds to a unit price increase of 6.4 per cent within six years.

In addition to the Eurofighter 2000 Typhoon, this research analysed two additional air force procurement objects. In 1957, the German air force started the search for a new interceptor. Within the same year the tactical situation changed, requiring the new warplane to also fulfil a fighter-bomber role. In the year 1958, the Bundeswehr decided to procure the F-104-G Starfighter. The first of 916 of these machines was delivered in 1961, and the last of these planes were used until 1991 (Luftwaffe 2006). The calculations of minimum and maximum unit price indices resulted in the values of 1.41 and 1.984. According to these values, the unit price increased by a percentage that is between 41 and 98.4 per cent.

The MRCA-Tornado is the second air force procurement object that has been analysed in this research. The development of this warplane started in 1967. Overall, 805 MRCA-Tornado 
systems have been delivered between 1980 and 1989. This delivery was divided into six tranches. Unlike the Starfighter and the Typhoon, this warplane was developed as a tactical fighter-bomber only (Ambos 1979; Schmidt 1979; Liebau 2002; Royal Air Force Historical Society 2002; Luftwaffe 2011). The analysis for this plane resulted in an unit price increase of 127.1 per cent, which was calculated based on the obtained unit price index of 2.271. The system price increase lies between 89 and 117.4 per cent, given the calculated maximum and minimum system price indices of 2.174 and 1.89 , respectively.

The only navy procurement object that has been analysed is the submarine type 212. The contract that confirmed the procurement of the first tranche of these fuel cell propelled submarine was signed in 1994. The four submarines that made up the first tranche have been delivered between the years of 2005 and 2006. The two additional submarines that constitute the German portion of the second tranche are still in delivery (Bundesregierung 2010; BMVg 2006; Behling 2003; Rauch and Dinse 1998). The first public unit price data for this system were announced in 1991. The unit price index that has been calculated using the data from 1991 and 2009 results in a value of 0.995 , which corresponds to a unit price decrease of 0.5 per cent.

\section{Discussion}

By transferring the results of the analysed single projects back to the analysis framework, we can compare the cost development percentages. Each single case and its cost development are placed into the overarching framework. By doing so, it is possible to generate insight into why certain projects have significantly higher cost increases than others (Figure 4).

Overall, we could not find any clear tendency pervading that the costs of major weapon acquisition projects in Germany increase over time. It appears that the three considered air force projects all have similar cost increase rates of approximately 100 per cent (apart from "best case" calculations for Tornado and Starfighter, which are below 100 per cent). Only the worst calculation for the APC HS 30 shows a comparable cost increase ratio, whereas all other calculations for army and navy objects remained far below this figure. We could only evaluate one navy case, which actually shows cost savings over time. However, this single navy case is not enough to prove that cost estimations for navy projects are more accurate than estimates for other services. Nevertheless, cost developments for army projects also stay far below those for air force projects. 


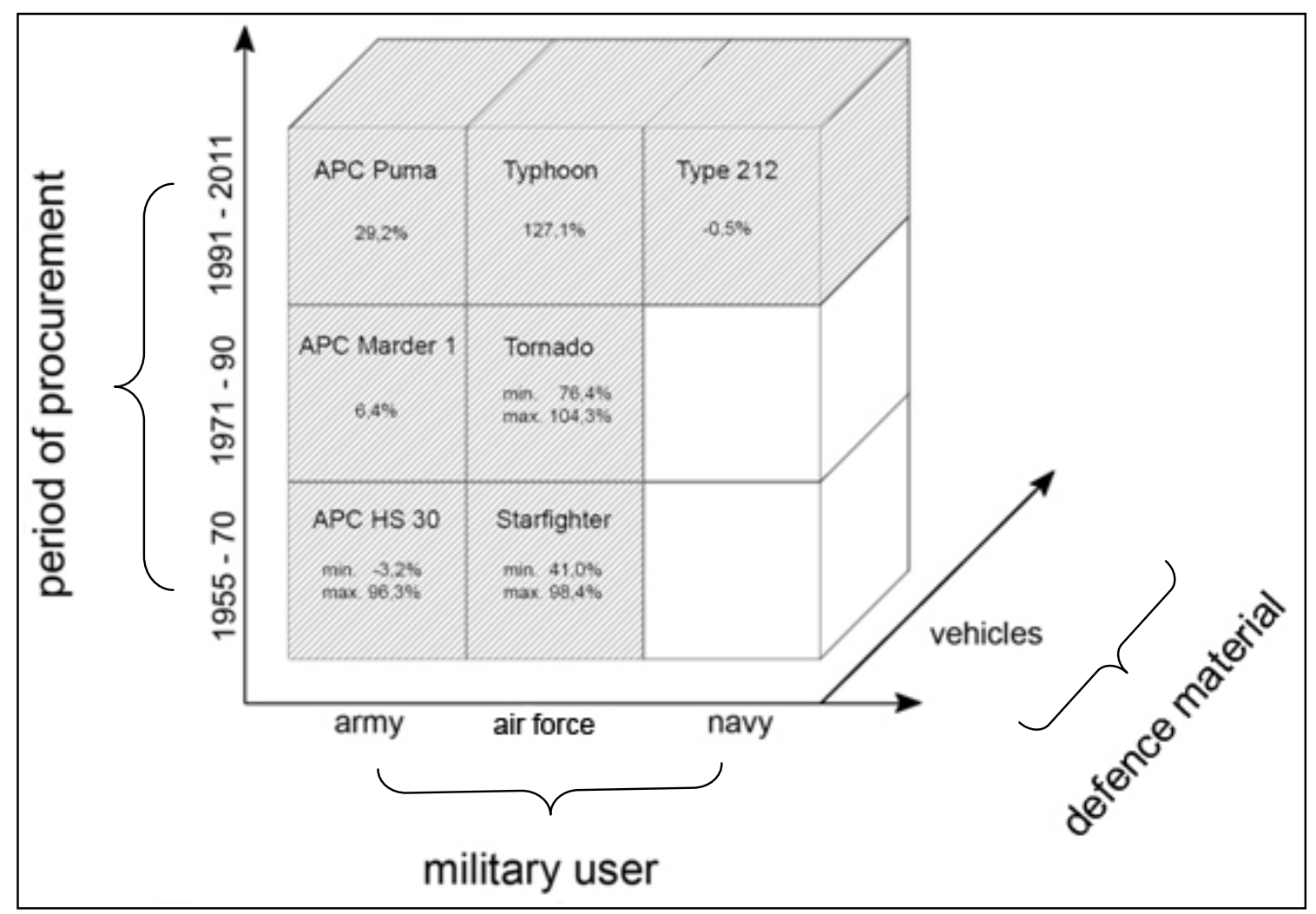

\section{Figure 4. Empirically analysed cost increases of major weapon systems.}

Compared to the general inflation rate of the European Union of all 27 member states which is 2,5 per cent from the year 2000 to 2012 (Eurostat 2012), the analyzed weapon systems have the following average cost increase ratios per year according to the data of figure 4: APC HS 30 (1956-1961): 19.26 per cent; APC Marder (1969-1975): 1,67 per cent; APC Puma (20042011): 4.17 per cent; Starfighter (1958-1968): 9,84 per cent; Tornado (1970-1981): 9.48 per cent; (Eurofighter (1994-2009): 8.47 per cent; Submarine Type 212 (1991-2009): -0,02 per cent. Even if in almost every project, the cost increase is higher than the general inflation rate, we did not find any tendency in this data that modern projects are more likely to cost more (have a higher Paache index) than projects several decades ago.

Other studies identified a linear or even progressive increase of costs over time (Kirkpatrick 2004; Pugh 2007). The cost increase ratios per year of our data is in line with those studies, which identified out of 30 different weapon systems a cost increase rate per year of between 5 and 10 per cent (Pugh 1994, Kirkpatrick).

In addition to earlier studies, our data and methodology examined the cost increase of a weapon system, as a ratio by itself. The results of this analysis cannot support the argument that the costs increase rate steadily rises over time. Modern systems do not have significant 
higher cost increase ratios than older ones. But specific services and their vehicles have higher cost increase ratios than vehicles of other services, e.g. aircrafts have a Paache index of about 100 per cent cost increase, while army APCs have a Paache index which indicates an average cost increase of "only" 27 per cent.

Other studies explored the technological, political and industrial reasons for cost increases (Kirkpatrick 2004). As we do not examine the causes of the cost increase rates in this paper, the explanatory power of this analysis is limited. Our findings base on cost developments for major weapon systems only, using the Paasche index methodology.

\section{Conclusion}

Critics of high defence spending costs often argue their case based on acquisition projects and their costs with respect to the planned budget (Drezner et al. 1993; Christensen et al. 1999). We introduced a new perspective on the problem of cost overruns in defence acquisition by applying another methodology. The Paasche index, closely adapted from market basket comparison techniques, allowed us to calculate the cost development of acquisition projects over time and to compare the cost increase of different projects. We rely greatly on the data used in calculating our results. As we had only limited access to actual contract prices of acquisition organisations or defence industry firms, we decided to focus on publicly available data only (literature, journals, press) because these are the (primary) sources of information for the public. As we compared and matched data from very different sources (literature, official publications, "grey" media publications) we improved the reliability of our data. However, as aforementioned, there was only limited access to real contract data. Given this database, the validity of our results is high, as the Paasche index provides transparent and reproducible calculations for each weapon system.

Using this method, we intended to challenge the public perception and the aforementioned other studies addressing cost increases in defence acquisition. In contrast to these investigations, we could not find any clear trend that indicates that modern weapon systems have a significantly higher (or lower) cost increase ratio than was observed for projects several decades before. However, it appears that, within a specific service or a specific vehicle type (tank, fighter jet, ship/boat), cost increases may be similar over time.

Our research is based on seven chosen acquisition projects for military vehicles only. Therefore, this result is only a first step for further and broader empirical analysis of acquisition programmes of major weapon systems. Although our findings in this work are 
limited and can therefore only indicate the price development for analysed objects, we perceive the usefulness of our methodology for the military, public, and further research. Similar to other studies (Pugh 2007), which emphasize not the causes but the consequences of the results, we suggest that in the early phases of new acquisition projects, valid Paasche indices for similar systems might be useful for assessing the potential tendencies for future cost developments. This could assist the military in evaluating cost developments in its budget plan. In addition, the public and politicians could evaluate the success of an allegedly "unique" acquisition project by relating it to data from similar projects in other decades or services. Further research may support these practical implications by improving the methodology for this special context of military acquisition projects. New areas of research can perhaps be guided by the analysis framework. In particular, the next investigative steps might focus on other dimensions of the framework, e.g., command and control equipment. Moreover, other studies might exploit how to use the derived data from a Paasche index of past acquisition projects to assess the anticipated cost developments for a new weapon system. 


\section{Appendix}

Collected data: APC HS 30

\begin{tabular}{|c|c|c|c|}
\hline Year & Unit price & Project & Quantity \\
\hline 1956 & $\begin{array}{l}76693,78 €(\text { Kollmer 2002) } \\
117597,13 €(\text { Kollmer 2002) } \\
127822,97 €(\text { Kollmer 2002) }\end{array}$ & $\begin{array}{l}\text { 1,424 bn. } €(\text { Engelmann } 1967 ; \\
\text { Kollmer 2002) }\end{array}$ & $\begin{array}{l}882 \text { - } 10680 \text { (Kollmer } \\
2002)\end{array}$ \\
\hline 1957 & $\begin{array}{l}153387,56 €(\text { Kollmer 2002) } \\
102258,38 €(\text { Kollmer 2002) } \\
115040,67 €(\text { Kollmer 2002) } \\
77716,37 €(\text { Kollmer 2002) }\end{array}$ & - & $\begin{array}{l}30 \text { (Kollmer 2002) } \\
2800 \text { (Kollmer 2002) } \\
1612(\text { Kollmer 2002) }\end{array}$ \\
\hline 1958 & $\begin{array}{l}\text { 97145,46 €(Kollmer 2002) } \\
89476,08 €(\text { Kollmer 2002) } \\
71580,86 €(\text { Kollmer 2002) } \\
69024,40 €(\text { Kollmer 2002) }\end{array}$ & - & $\begin{array}{l}2800 \text { (Scheibert 1987) } \\
1612 \text { (Kollmer 2002; Plate } \\
\text { 2005) }\end{array}$ \\
\hline 1961 & $\begin{array}{l}165147,28 €(\text { Kollmer 2002) } \\
135706,69 €(\text { Kollmer 2002) }\end{array}$ & - & - \\
\hline 1962 & - & - & 2176 (Engelmann 1967) \\
\hline
\end{tabular}

Tab. 1 unit prices, project costs and quantity of the HS 30 from 1956 to 1962

Collected data: APC Marder

\begin{tabular}{|c|c|c|c|}
\hline Year & Unit price & Project & Quantity \\
\hline 1969 & $357904,32 €($ Der Spiegel 1969) & 0,901 bn. $€($ Die Zeit 1969) & 2171 (Die Zeit 1969) \\
\hline 1971 & $\begin{array}{l}383468,91 €(\text { Die Zeit } 1971) \\
400000,00 €(\text { Der Spiegel 2011a; } \\
\text { Blume 2007) } \\
511291,88 €(\text { Hilmes } 2006)\end{array}$ & - & $\begin{array}{l}1926 \text { (Die Zeit 1971) } \\
2136 \text { (Scheibert 1987) }\end{array}$ \\
\hline 1972 & $398202,40 €($ Der Spiegel 1972) & 0,767 bn. $€$ (Der Spiegel 1972) & $\begin{array}{c}1926 \text { (600) (Spiegel } \\
1972)\end{array}$ \\
\hline 1975 & - & 306,775 m. € (Der Spiegel 1975) & 600 (Der Spiegel 1975) \\
\hline 2011 & $50000,00 €($ Spiegel 2011a) & - & - \\
\hline
\end{tabular}

Tab. 2 unit prices, project costs and quantity of the Marder from 1969 to 2011

Collected data: APC Puma

\begin{tabular}{|c|c|c|c|c|}
\hline Year & Unit price & Project & Quantity & Year \\
\hline 2002 & - & $\begin{array}{l}4,878 \mathrm{~m} . € \\
(\mathrm{FAZ} 2002)\end{array}$ & 2 bn. $€$ & 410 (FAZ 2002) \\
\hline 2004 & $\begin{array}{l}6,261 \mathrm{~m} . € \\
(\mathrm{BWB} 2011)\end{array}$ & $\begin{array}{l}7,511 \mathrm{~m} . € \\
(\mathrm{BWB} 2011)\end{array}$ & $\begin{array}{l}360 \text { m. } €(\text { Rheinmetall 2004) } \\
3,05 \text { bn. } €(\text { Jane's Defence Weekly } \\
2004)\end{array}$ & $\begin{array}{l}5 \text { (410) (Jane's Defence } \\
\text { Weekly 2004) }\end{array}$ \\
\hline 2005 & - & - & 3 bn. $€$ (Lange 2005$)$ & 410 (Lange 2005) \\
\hline 2006 & - & - & 3,4 bn. $€($ Sollorz 2006) & 410 (Sollorz 2006) \\
\hline 2007 & - & - & 3,846 bn. $€($ BMVg 2006) & - \\
\hline 2008 & - & - & 3,888 bn. $€($ BMVg 2007) & - \\
\hline 2009 & - & - & $\begin{array}{l}\text { 3,1 bn. } €(\text { Ernst 2009; Der Spiegel } \\
\text { 2009; Müller 2009; Reisener 2009) } \\
\text { 4,789 bn. } €(\text { BMVg 2008) }\end{array}$ & $\begin{array}{l}405 \text { (410) (Ernst 2009; } \\
\text { Müller 2009) }\end{array}$ \\
\hline 2010 & - & - & 4,2 bn. $€($ BMVg 2010) & 410 (BMVg 2010) \\
\hline 2011 & $\begin{array}{l}9,258 \mathrm{~m} . € \\
\text { (BWB 2011) }\end{array}$ & $\begin{array}{l}9,791 \mathrm{~m} . € \\
\text { (BWB 2011) }\end{array}$ & - & - \\
\hline
\end{tabular}

Tab. 3 unit prices, project costs and quantity of the Puma from 2002 to 2011 
Collected data: Submarine Type 212

\begin{tabular}{|c|c|c|c|}
\hline Year & Unit price & Project & Quantity \\
\hline 1991 & $319,5 \mathrm{~m} . €($ Die Zeit 1991) & 1,278 bn. $€($ Die Zeit 1991$)$ & 4 (Die Zeit 1991) \\
\hline 1993 & - & 1,6 bn. $€$ (Behling 2003) & - \\
\hline 1994 & - & 1,329 bn. $€($ Gose 2000$)$ & 4 (Gose 2000$)$ \\
\hline 1996 & - & $\begin{array}{l}1,329 \text { bn. } €(\text { Spiegel 1996) } \\
1,431 \text { bn. } €(\text { (Die Zeit 1996) }\end{array}$ & $\begin{array}{l}4 \text { (Die Zeit 1996; Der } \\
\text { Spiegel 1996) }\end{array}$ \\
\hline 2000 & $383,469 \mathrm{~m} . €($ Gose 2000$)$ & - & - \\
\hline 2004 & $\begin{array}{l}425 \text { m. } € \text { (Weckbach-Mara } \\
2002)\end{array}$ & 1,7 bn. $€$ (Weckbach-Mara 2002) & 4 (Weckbach-Mara 2002) \\
\hline 2005 & - & 790 m. $€$ (Lange 2005) & \\
\hline 2007 & - & 824 m. $€($ BMVg 2006) & - \\
\hline 2008 & - & 915 m. $€($ BMVg 2007 & - \\
\hline 2009 & 464,5 m. $€($ BMVg 2008) & $929 \mathrm{~m} . €(\mathrm{BMVg} 2008)$ & 2 (BMVg 2008) \\
\hline
\end{tabular}

Tab. 4 unit prices, project costs, lots and quantity of the Type 212 from 1991 to 2009

Collected data: F-104 G Starfighter

\begin{tabular}{|c|c|c|c|c|}
\hline Year & Unit price & System price & Project & Quantity \\
\hline 1958 & $\begin{array}{l}2,045 \text { m. } €(\text { Johannson 1969) } \\
2,301 \text { m. } €(\text { Engelmann 1967) }\end{array}$ & - & - & - \\
\hline 1959 & $\begin{array}{l}\text { 2,965 m. } €(\text { Schlotter 1967; } \\
\text { Wache 2003) }\end{array}$ & - & - & $\begin{array}{c}\text { 30, 66, } 210 \\
\text { (Johannson } \\
\text { 1969; Wache } \\
\text { 2003) } \\
\end{array}$ \\
\hline 1959 & $\begin{array}{l}2,369 \text { m. } €(\text { Schlotter 1967) } \\
2,471 \text { m. } €(\text { Schlotter 1967) } \\
\text { 2,597 m. } €(\text { Schlotter 1967) }\end{array}$ & - & $\begin{array}{l}1,278 \text { bn. } € \\
\text { (Schlotter 1967) }\end{array}$ & $\begin{array}{c}264-364 \\
\text { (Schlotter } \\
1967) \\
\end{array}$ \\
\hline 1965 & $2,812 \mathrm{~m} . €($ Schlotter 1967) & - & - & - \\
\hline 1966 & 3,068 m. € (Der Spiegel 1966) & - & - & - \\
\hline 1967 & - & $\begin{array}{l}3,835 \text { m. } € \text { (Schlotter } \\
1967)\end{array}$ & $\begin{array}{l}3,068 \text { bn. } € \\
\text { (Schlotter 1967) }\end{array}$ & - \\
\hline 1968 & $\begin{array}{l}\text { 4,09 m. } €(\text { Johannson 1969) } \\
5,113 \mathrm{~m} . €(\text { Johannson 1969) }\end{array}$ & $\begin{array}{l}5,829 \text { m. } € \text { (Johannson } \\
1969)\end{array}$ & $\begin{array}{l}0,282 \text { bn. } € \\
\text { (Johannson 1969) }\end{array}$ & $\begin{array}{c}50 \text { (Johannson } \\
\text { 1969) }\end{array}$ \\
\hline 1970 & - & - & $\begin{array}{l}0,230 \text { bn. } € \\
(\text { Johannson 1969) }\end{array}$ & $\begin{array}{c}50 \text { (Johannson } \\
1969) \\
\end{array}$ \\
\hline
\end{tabular}

Tab. 5 unit prices, project costs and quantity of the F 104 G Starfighter from 1958 to 1970 
Collected data: MRCA Tornado

\begin{tabular}{|c|c|c|c|c|}
\hline Year & Unit price & System price & Project & Quantity \\
\hline 1968 & $\begin{array}{l}5,113 \text { m. } €(\text { Schmidt } 1979 ; \\
\text { Albrecht u.a. 1974) }\end{array}$ & - & - & $\begin{array}{l}1500 \text { (Royal Air } \\
\text { Force Historical } \\
\text { Society 2002) }\end{array}$ \\
\hline 1969 & 5,113 m. € (Albrecht et al. 1974) & $\begin{array}{l}11,453 \mathrm{~m} . € \text { (Albrecht et } \\
\text { al. 1974) }\end{array}$ & - & $\begin{array}{l}1085-1285 \\
\text { (Schmidt 1979; } \\
\text { (Royal Air Force } \\
\text { Historical Society } \\
\text { 2002; Grossner, } \\
\text { Schierholz 1974) }\end{array}$ \\
\hline 1970 & $\begin{array}{l}\text { 7,286 m. } €(\text { Grossner, } \\
\text { Schierholz 1974; Ambos 1979) } \\
7,593 \text { m. } € \\
<7,669 \text { m. } € \\
8,180 \text { m. } €(\text { Schmidt } 1979) \\
8,436 \text { m. } €(\text { Schmidt } 1979 ; \\
\text { Grossner, Schierholz 1974) }\end{array}$ & $\begin{array}{l}\text { 5,113 m. } € \text { (Albrecht et } \\
\text { al. 1974) } \\
7,669 \text { m. } € \text { (Schmidt } \\
1979)\end{array}$ & - & $\begin{array}{l}905 \\
\text { (Royal Air Force } \\
\text { Historical Society } \\
\text { 2002) }\end{array}$ \\
\hline 1971 & 7,158 m. $€($ Ambos 1979) & $\begin{array}{l}17,895 \mathrm{~m} . € \text { (Albrecht et } \\
\text { al. 1974) }\end{array}$ & - & - \\
\hline 1972 & $\begin{array}{l}15,339 \text { m. } €(\text { Schmidt 1979) } \\
16,361 \mathrm{~m} . € \text { (Albrecht et al. 1974) }\end{array}$ & $\begin{array}{l}25,564 \mathrm{~m} . € \text { (Albrecht et } \\
\text { al. 1974) }\end{array}$ & - & $\begin{array}{l}809 \\
\text { (Royal Air Force } \\
\text { Historical Society } \\
\text { 2002) }\end{array}$ \\
\hline 1973 & 10,226 m. $€($ Ambos 1979) & $\begin{array}{l}17,895 \text { m. } €(\text { Der Spiegel } \\
1974)\end{array}$ & $\begin{array}{l}8,180 \text { bn. } € \\
\text { (Schmidt } \\
1979)\end{array}$ & - \\
\hline 1974 & $\begin{array}{l}10,226 \text { m. } €(\text { Ambos 1979) } \\
15,461 \text { m. } € \text { (Albrecht et al. 1974) }\end{array}$ & $\begin{array}{l}22,752 \text { m. } €(\text { Der Spiegel } \\
1974)\end{array}$ & - & $\begin{array}{l}807 \text { (Der Spiegel } \\
1974)\end{array}$ \\
\hline 1975 & $\begin{array}{l}12,271 \mathrm{~m} . €(\text { Ambos 1979) } \\
13,498 \text { m. } €\end{array}$ & - & - & - \\
\hline 1977 & $\begin{array}{l}\text { 14,306 m. } €(\text { Schmidt 1979) } \\
17,42 \text { m. } €(\text { Ambos 1979) }\end{array}$ & $\begin{array}{l}26,132 \text { m. } €(\text { Schmidt } \\
1979)\end{array}$ & $\begin{array}{l}8,414 \text { bn. } € \\
\text { (Schmidt } \\
1979) \\
10,392 \text { bn. } €\end{array}$ & - \\
\hline 1978 & - & $\begin{array}{l}35,790 \text { m. } € \text { (Schmidt } \\
1979)\end{array}$ & - & - \\
\hline 1979 & $\begin{array}{l}17,946 \text { m. } €(\text { Liebau 2002) } \\
18,028 \text { m. } €(\text { Ambos 1979) } \\
22,962 \text { m. } €\end{array}$ & $\begin{array}{l}34,44 \text { m. } €(\text { Ambos } \\
1979)\end{array}$ & - & 805(Ambos 1979) \\
\hline 1981 & 25,287 m. € (Liebau 2002) & - & - & 40 (Liebau 2002) \\
\hline 1982 & 18,966 m. € (Liebau 2002) & - & - & 105 (Liebau 2002) \\
\hline 1984 & 17,701 m. € (Liebau 2002) & - & - & 165 (Liebau 2002) \\
\hline 1985 & 16,858 m. $€($ Liebau 2002) & - & - & 165 (Liebau 2002) \\
\hline 1986 & 16,015 m. $€($ Liebau 2002) & - & - & 165 (Liebau 2002) \\
\hline 1987 & 15,242 m. € (Liebau 2002) & - & - & 165 (Liebau 2002 \\
\hline
\end{tabular}

Tab. 6 unit prices, system prices, project costs and quantity of the MRCA Tornado from 1968 to 1988 
Collected data: Eurofighter 2000 Typhoon

\begin{tabular}{|c|c|c|c|c|}
\hline Year & Unit price & System price & Project & Quantity \\
\hline 1988 & - & 33,234 m. €. (Der Spiegel 1994) & - & $\begin{array}{c}250(\text { Der } \\
\text { Spiegel 1994) }\end{array}$ \\
\hline 1991 & - & $\begin{array}{l}\text { 47,167 m. € (Brzoska, Voß 1996; } \\
\text { Spiegel 1992) }\end{array}$ & - & $\begin{array}{l}200 \text { (Brzoska, } \\
\text { Voß 1996; Der } \\
\text { Spiegel 1992) }\end{array}$ \\
\hline 1992 & - & $\begin{array}{l}\text { 54,095 -102,258 m. } €(\text { Brzoska, Voß } \\
\text { 1996; Der Spiegel 1992) } \\
\text { 51,129 - 66,468 m. € (Brzoska, Voß } \\
\text { 1996) } \\
\text { 76,694 m. € (Brzoska, Voß 1996) } \\
\text { 68,462 m. € (Der Spiegel 1994) } \\
\text { 46,016 m. } €(\text { Der Spiegel 1992) } \\
\text { 46,016 - 51,129 m. € (Der Spiegel } \\
\text { 1992) } \\
\text { 52,125 m. € (Brzoska, Voß 1996) }\end{array}$ & - & - \\
\hline 1993 & - & $\begin{array}{l}76,694 \text { m. } €(\text { Brzoska, Voß 1996) } \\
\text { 46,016 m. } €(\text { Brzoska, Voß 1996) } \\
\text { 52,407 m. } €(\text { Der Spiegel 1994) }\end{array}$ & $\begin{array}{l}6,442 \text { bn. } € \\
\text { (Brzoska, Voß } \\
1996)\end{array}$ & $\begin{array}{l}140 \text { (Brzoska, } \\
\text { Voß 1996; Der } \\
\text { Spiegel 1994) }\end{array}$ \\
\hline 1994 & $\begin{array}{l}\text { 29,553 m. (Brzoska, } \\
\text { Voß 1996; Stauch, } \\
\text { Hofmann 1994) }\end{array}$ & $\begin{array}{l}\text { 66,468 m. } €(\text { Stauch, Hofmann 1994) } \\
\text { 76,694 Mio. } €(\text { Brzoska, Voß 1996) }\end{array}$ & - & - \\
\hline 1995 & $\begin{array}{l}37,58 \text { m. } €(\text { Brzoska, } \\
\text { Voß 1996) }\end{array}$ & $\begin{array}{l}65,108 \text { m. } €(\text { Brzoska, Voß 1996) } \\
80,784 \text { m. } €(\text { Brzoska, Voß 1996) }\end{array}$ & $\begin{array}{l}6,902 \text { bn. } € \\
\text { (Brzoska, Voß } \\
1996)\end{array}$ & - \\
\hline 1996 & - & 44,147 m. $€($ Cook 1996) & - & - \\
\hline 1997 & - & - & $\begin{array}{l}11,7 \text { bn. } € \text { (Sutton } \\
1997)\end{array}$ & $\begin{array}{c}180 \\
\text { (Sutton 1997) }\end{array}$ \\
\hline 2003 & - & $62 \mathrm{~m} . €($ Weckbach-Mara 2002) & $\begin{array}{l}11,16 \text { bn. } € \\
\text { (Weckbach-Mara } \\
2002 \text { ) } \\
19,5 \text { bn. } €(\text { Der } \\
\text { Spiegel 2003) }\end{array}$ & $\begin{array}{c}180 \\
\text { (Weckbach- } \\
\text { Mara 2002) }\end{array}$ \\
\hline 2004 & $\begin{array}{l}85,7 \mathrm{~m} . €(\text { defense- } \\
\text { aerospace.com 2006) }\end{array}$ & $\begin{array}{l}118,3 \text { m. } €(\text { defense-aerospace.com } \\
2006) \\
136,1 \text { m. } €(\text { Henken } 2005)\end{array}$ & $\begin{array}{l}18 \text { bn. } € \\
\text { (Handelsblatt } \\
2004 \text { ) } \\
21,3 \text { Mrd. } €\end{array}$ & $\begin{array}{c}180 \\
\text { (Handelsblatt } \\
\text { 2004) }\end{array}$ \\
\hline 2005 & - & 85,7 m. $€$ (Kirschner 2006) & $\begin{array}{l}24 \text { bn. } € \\
\text { (Kirschner 2006) }\end{array}$ & $\begin{array}{c}180 \\
\text { (Lange 2005) } \\
\end{array}$ \\
\hline 2007 & - & 120 m. $€($ Der Tagesspiegel 2007) & - & - \\
\hline 2009 & $\begin{array}{l}86 \text { m. } €(\text { Fasse, } \\
\text { Brüggmann 2009) }\end{array}$ & 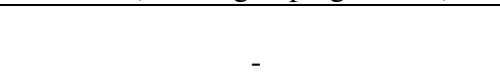 & $\begin{array}{l}2,87 \text { bn. } € \text { (Heilig } \\
2009)\end{array}$ & - \\
\hline
\end{tabular}

Tab. 7 unit prices, system prices, project costs and quantity of the Eurofighter Typhoon from 1988 to 2009 


\section{References}

Albrecht, U./Burkhard, L./Schlotter, P. (1974), Das Ende des MRCA?, in: Ein Antiweißbuch, Material für eine alternative Militärpolitik, Hamburg 1974.

Allen, R.G.D. (2008), Index numbers in economic theory and practice, AldineTransaction, Piscataway, N.J.

Ambos, H. (1980), Kostenentwicklung komplexer Waffensysteme - Beispiel MRCA Tornado, in: Wehrtechnik, Vol. 12, 1980, pp. 33 - 38.

Arena, M.V./Leonard, R.S./Murray, S.E./Obaid, Y. (2006), Historical Cost Growth of Completed Weapon System Programs, Santa Monica, CA.

Barber, E./Parsons, N. (2009), A Performance Model to Optimize the Capability Choices Made in the Procurement Phase within the Australian Defense Force, in: International Journal of Defense Acquisition Management, Vol. 2, 2009, pp. 32 - 48.

Behling, F. (2003), Auch im U-Boot-Bau wird es für HDW langsam eng, in: Kieler Nachrichten, 1st September 2007, pp. $1-2$.

Bogan, C.E./English, M.J. (1994), Benchmarking for Best Practices, McGraw-Hill, New York.

Böhnert, A. A. (1999), Benchmarking, Hamburg.

Behling, F. (2003), Auch im U-Boot-Bau wird es für HDW langsam eng, in: Kieler Nachrichten, 01.09.2007, pp. 1 - 2.

Bellmann, J./Knorr, A./Schomaker, R. (2011), Factors influencing time and cost overruns in aircraft projects, in: Aerlines, Vol. 49., 2011, H. 1, pp. 1 - 4; available at: http://www.aerlines.nl/wp-content/uploads/2011/01/49_Bellmann_Knorr_SchomakerDelay_Cost_Overrun_Aircraft_Programs1.pdf, accessed 21st November 2011.

Blume, P. (2007), SPz Marder - Der Schützenpanzer der Bundeswehr - Geschichte, Einsatz, Technik, Erlangen.

BMVg (2006), Bundeswehrplan 2007, Berlin 2006.

BMVg (2007), Bundeswehrplan 2008, Berlin 2007.

BMVg (2008), Bundeswehrplan 2009, Berlin 2008.

BMVg (2010), Die Bedeutung des Projektes SPz Puma für den Rüstungsbereich, in: Wehrtechnischer Report, Vol. 6/2010, pp. $11-12$.

Brzoska, M. (1995), World Military Expenditures, in: Hartley, K./Sandler, T. (Eds.), Handbook of defense economics, Amsterdam, pp. 45 - 67.

Brzoska, M./Voss, W. (1996), Auswirkungen und Alternativen des Eurofighter 2000: Eine Vier-Länder-Studie für das Internationale Konversationszentrum Bonn, Baden Baden.

Bundesbank (2011), Zeitreihe UJFB99: Verbraucherpreisindex / bis 1994: Westdeutschland / 1) 2) 3) 4); available at: http://www.bundesbank.de/statistik/statistik_zeitreihen.php?lang=de\&open=konjunktur\&f unc $=$ row\&tr $=$ UJFB99, accessed: 25th June 2011.

Bundesregierung (2010), Drucksache 17/2686 - Antwort der Bundesregierung auf die Kleine Anfrage der Abgeordneten Uwe Beckmeyer, Garrelt Duin, Hubertus Heil (Peine), weiterer Abgeordneter und der Fraktion der SPD (Drucksache 17/2522). 
BWB (2011), Vorhaben SPz Puma - Darstellung der Fahrzeugpreisentwicklung von 12/2004 bis 2011, Koblenz 2011.

Camp, R.C., (1989), Benchmarking: The search for industry best practices that lead to superior performance, Quality Resources, New York.

Christensen, D.S./Searle, D.A./Vickery, C. (1999), The impact of the packard commission`s recommendations on reducing cost overruns on defense acquisition contracts, in: Acquisition Review Quarterly, Summer 1999, pp. 251 - 262.

Cook, N. (1996), EF 2000: rough ride nearly over?, in: Interavia Business \& Technology, 51, p. 38.

Defense-Aerospace.com (2006), Sticker Shock: Estimating the Real Cost of Modern Fighter Aircraft, report of www.defense-aerospace.com.

Departement of Defense (DoD) (2001), Product Support for the 21st Century: A Program Manager's Guide to Logistics, available at: https://acquisition.navy.mil/content/download/376/1164/file/perfbasedguide.pdf, accessed 3rd November 2011.

Dillard, J.T. (2005), Toward centralized control of defense acquisition programs, in: Defense Acquisition Review Journal, Vol. 12 (3), pp. 331 - 344.

Drezner, J.A./Jarvaise, J./Hess, R./Hough, P./Norton, D. (1993), An analysis of weapon system cost growth, RAND Corporation, Santa Monica CA.

Der Spiegel (1969), Bundeswehr Schützenpanzer - Kontur verschwimmt, in: Der Spiegel, Vol. 37, 12.05.1969, pp. $39-41$.

Der Spiegel (1966), Starfighter-Asse Kündigten, in: Der Spiegel, Vol. 34, 14.08.1966, p. 21.

Der Spiegel (1972), Schöner Brocken, in: Der Spiegel, Vol. 19, 01.05.1972, pp. 33 - 34.

Der Spiegel (1975), Warum liefern die Deutschen keine Panzer?, in: Der Spiegel, Vol. 38, 15.09.1975, pp. $39-57$.

Der Spiegel (1992), Wie beim Jo-Jo, in: Der Spiegel, Vol. 48, 23.11.1992, pp. 29 - 30.

Der Spiegel (1994), Alles Armleuchter, in: Der Spiegel, Vol. 35, 29.08.1994, p. 23.

Der Spiegel (1996), Schiffbau: Kaltes Herz, in: Der Spiegel, Vol. 3, 15.01.1996, pp. 184-185.

Der Spiegel (2003), Eurofighter bedingt tauglich, in: Der Spiegel, Vol. 37, 08.09.2003, p. 20.

Der Spiegel (2009), Bundestag genehmigt umstrittenen Kauf von „Puma“ - Panzern, available at: http://www.spiegel.de/politik/ deutschland/0,1518,631067,00.html, update: 17 th June 2009.

Der Spiegel (2011a), Billiger Leo, in: Der Spiegel, Vol. 6, 07.02.2011, p. 17.

Die Zeit (1969), Zeitraffer - Lohn fürs Sparen, in: Die Zeit, Vol. 24, 13.06.1969, p. 1.

Die Zeit (1971), Report aus Bonn, in: Die Zeit, Vol. 23, 04.07.1971, pp. 1 - 3.

Die Zeit (1991), Ein Phantom auf Tauchfahrt, in: Die Zeit, Vol. 50, 06.12.1991, pp. 1 - 4.

Die Zeit (1996), Leise Bedrohung, in: Die Zeit, Vol. 23, 31.05.1996, pp. 1 - 3.

Der Tagesspiegel (2007), Kunden Kämpfen mit Eurofighter, available at: http://www.tagesspiegel.de/wirtschaft/kunden-kaempfen-mit-eurofighter/1117378.html, update: 10th December.2007.

Dresen, P. (1997), Benchmarking in der Beschaffung, Düsseldorf et al. 1997. 
Ellram, L.M. and Siferd, S.P. (1998), Total cost of ownership: A key concept in strategic cost management decisions, in: Journal of Business Logistics, Vol. 19, 1998, 1, pp. 55 - 84.

Engelmann, B. (1967), Schützenpanzer HS 30 Starfighter F-4 G - oder Wie man unseren Staat zugrunde richtet, München 1967.

Ernst, D. (2009), Rheinmetall erhält Milliardenauftrag für neuen Panzer, available at: http://www.derwesten.de/nachrichten/ wirtschaft-und-finanzen/Rheinmetall-erhaeltMilliarden-Auftrag-fuer-neue-Panzer-id411151.html, update: 6th July 2009.

Eurostat (2011), Jährliche Inflationsrate im Euroraum auf 2,7\% gesunken, Pressemitteilung des Statistischen Amtes der EU, Vol. 87, 16.06.2011.

Eurostat (2012), HVPI Inflation Rate, available at: $\mathrm{http}: / /$ epp.eurostat.ec.europa.eu/tgm/table.do?tab=table $\&$ language $=$ de $\&$ pcode $=$ tsieb060 $\&$ ta bleSelection=1\&footnotes=yes\&labeling=labels\&plugin=1, accessed 10th April 2012.

FAZ (2002), Neuer Schützenpanzer kommt früher und billiger, available at: http://www.faz.net/s/RubA24ECD630CAE40E483841DB7D16F4211/ Doc EE715FD6F649144DFA64B811BE998C915 ATpl Ecommon Scontent.html, updated: 14th August 2002.

Fasse, M./Brüggmann, M. (2009), Endspiel um den Eurofighter beginnt, in: Handelsblatt, 54, 18.03.2009, p. 14.

Ferrara, J. (1996), DOD’s 500 documents: evolution and change in defense acquisition policy, in: Acquisition Review Quarterly, Fall 1996, pp. 109 - 130.

Fisher, I. (1922), The Making of Index Numbers - A Study of their Varieties, Tests and Reliablity, Bosten and New York.

Gaul, C.- M. (2008), Verbraucherpreisentwicklung, Informationspapier des wissenschaftlichen Dienstes des Bundestages, Vol. 27, 29.04.2008.

Geary, S. /Vitasek, K. (2008), Performance-Based Logistics, A Contractor's Guide to Life Cycle Product Support Management, Stoneham, Bellevue.

Gose, S. (2000), Verteidigungshaushalt 2001 - Etikettenschwindel Bundeswehrreform, in: AMI - Antimilitarismus Information, Vol. 11, 2000, pp. 17 - 30.

Grossner, H./Schierholz, H. (1974), Projekt MRCA - Dokumentation und Kritik des größten Rüstungsvorhabends der deutschen Geschichte, Köln 1974.

Handelsblatt (2004), Haushaltsauschuss billigt zweite Tranche für Eurofighter, available at: http://www.handelsblatt.com/archiv/haushaltsausschuss-billigt-zweite-tranche-fuereurofighter/2445806.html, update: 2nd December 2004.

Heilig, R. (2009), Zwischen Konkurrenz und Kooperation Europas Rüstung kostet Geld und Vernunft, in: Welttrends, 68, 2009, pp. $55-60$.

Henken, L. (2003), Zukünftigen Entwicklung der deutschen Militärausgaben, Studie des IMI e.V., Tübingen und Hamburg.

Henken, L. (2005), Europa MACHT Frieden, Positionspapier des IMI e.V., 2005/024, Tübingen und Hamburg 2005, pp. 1 - 6.

Hilmes, R. (2006), 50 Jahre Fahrzeuge der gepanzerten Kampftruppen, in: Das schwarze Barett, Vol. 35, 25.03.2006, pp. $1-10$. 
Hypko, P. /Tilebein, M. /Gleich, R. (2010b), Clarifying the concept of performance-based contracting in manufacturing industries, a research synthesis, in: Journal of Service Management, Vol. 21, 2010, 5, pp. 625 - 655.

IFHS (2010), Einsparungen bei den Staatsausgaben - welchen Spielraum gibt es bei der Bundeswehr?, Positionspapier der Kommission "Europäische Sicherheit und Zukunft der Bundeswehr" am IFSH, Hamburg 2010.

Jane's Defence Weekly (2004), Germany approves Puma, Typhoon spending, Europe, in: Jane's Defence Weekly, 10.12.2004, p. 12.

Johannson, K. (1969), Vom Starfighter zum Phantom, Frankfurt a. M.

Keller, T. (1996), Benchmarking Methoden und Techniken, Chemnitz.

Kirkpatrick, D.1. I. (2004), Trends in the costs of weapon systems and the consequences, in: Defence and Peace Economics, Vol. 15, 2004, 3, pp. 259 - 273.

Kirschner, S. (2006), EF 2000 Typhoon - Bits and Bolts, in: Der Mölderianer, 148, Neuburg 2006, pp. $21-26$.

Klos, D. (2011), Die neue Bundeswehr - Sachstand und Perspektiven, in: Europäische Sicherheit, available at: http://europaeische-sicherheit.de/Ausgaben/2011/02_2011/02_Klos/2011,02,02,01,.html, accessed 3rd November 2011.

Knight, H. (2002), Delays threaten Eurofighter Orders, in: The Engineer, Vol. 291, p. 7.

Kollmer, D. H. (2002), Rüstungsgüterbeschaffung in der Aufbauphase der Bundeswehr - Der Schützenpanzer HS 30 als Fallbeispiel (1953 - 1961), Stuttgart 2002.

Lange, S. (2005), Neue Bundeswehr auf altem Sockel - Wege aus dem Dilemma, Studie der Stiftung Wissenshaft und Politik, Berlin 2002.

Lau, H.C.W./Lee, W.B./Lau, P.H.K. (2001), Development of an intelligent decision support system for benchmarking assessment of business partners, in: Benchmarking: in International Journal, Vol. 8, pp. 376 - 395.

Liebau, H. (2002), Lernkurven - Erfolgsdokumentation stetiger Rationalisierungsarbeit, in: FB/IE, Vol. 51/3, 2002, pp. $124-129$.

Luftwaffe (2006), F-104 G Starfighter, available at: http://www.geschichte.luftwaffe.de/portal/a/geschlw/kcxml/04_Sj9SPykssy0xPLMnMz0v M0Y_QjzKLNwyL9_AwAMmB2e5eTvqRcNGglFR9X4_83FR9b_0A_YLciHJHR0VFA EAoQgI!/delta/base64xml/L2dJQSEvUUt3QS80SVVFLzZfMVZfSE1T?yw_contentURL $=\% 2 F 01 \mathrm{DB} 060000000001 \% 2 \mathrm{FW} 26 \mathrm{MBCXY020INFODE} \% 2 \mathrm{Fcontent}$.jsp, accessed 21st December 2006.

Luftwaffe (2007), Eurofighter; available at: http://www.geschichte.luftwaffe.de/portal/a/geschlw/kcxml/04_Sj9SPykssy0xPLMnMz0v M0Y_QjzKLNwyL9_AwBsmB2e5eTvqRcNGglFR9X4_83FR9b_0A_YciHJHR0VFAN0tBto!/delta/base64xml/L2dJQSEvUUt3QS80SVVFLzZfMVZf SEg2?yw_contentURL=\%2F01DB060000000001\%2FW26MFN3T280INFODE\%2Fconte nt.jsp, accessed 8th February 2007.

Luftwaffe (2011), Tornado - Beschreibung, available at: http://www.luftwaffe.de/portal/a/luftwaffe/kcxml/04_Sj9SPykssy0xPLMn Mz0vM0Y_QjzKLNzKIdw_wAM1B2F7O-pFw0aCUVH1vfV P_NxU_QD9gtyIckd HRUUAtJq8Bw!!/delta/base64xml/L2dJQSEvUUt3QS80SVVFLzZfMjBfMUE5Sg!!?yw_ 
contentURL=\%2F01DB060000000001\%2FW27ELGJQ447INFODE\%2Fcontent.jsp\#par3 , accessed: 9th February 2011.

Maire, J.-L. (2002), A model of characterization of the performance for a process of benchmarking, in: Benchmarking: An International Journal, Vol. 9, 2002, 5, pp. 506 -520.

Magd, H./Curry, A. (2003), Benchmarking: achieving best value in public-sector organizations, in: Benchmarking: An international Journal, Vol. 10, pp. 261-286.

Ministry of Defence (MoD) (1998), Strategic Defence Review (CM 3999), retrieved July 31, 2009, available at www.mod.uk, accessed at 3rd November 2011.

Müller, M. (2009), Bund bestellt halbfertigen Puma-Panzer, available at, http://www.fronline.de/wirtschaft/bund-bestellt-halbfertigen-puma-panzer/-/1472780/3297720//index.html, update: 7th September 2009.

$\mathrm{Ng}$, I.C.L./Nudurupati, S.S. (2010), Outcome-based service contracts in the defence industry, mitigating the challenges, in: Journal of Service Management, Vol. 21, 2010, 5, pp. 656 674.

Plate, J. (2005), Fahrzeuge der Bundeswehr seit 1955, Stuttgart.

Pinnekamp, H.J./Siegmann, F. (2001), Deskriptive Statistik, München.

PSM (2010), Fähigkeitsforderungen umgesetzt in technische Lösung - Gesamtsystem SPz Puma: Wehrtechnischer Report, Vol. 6, 2010, pp. 21 - 24.

Pugh, P.G. (1994), Performance-based cost estimation, Proceedings of the 13th International Cost Engineering Conference, London 1994.

Pugh, P.G. (2007), Retrospect and prospect: Trends in cost and their implications for UK aerospace, in: Defence and Peace Economics, Vol. 18, 2007, 1, pp. 25-37.

Rauch, H./Dinse, R. (1998), U-Boot Klasse 212 - Beschreibung und Status, in: Deutsche U-Boote heute und morgen, Wehrtechnischer Report, 2008, pp. 19 - 20.

Raymond, J. (2008), Benchmarking in public procurement. Benchmarking: An International Journal, Vol. 15, 2008, 6, pp. 782 - 793.

Reisener, T. (2009), Regierung bestellt 405 „Puma“-Panzer - Milliardenauftrag für Rheinmetall, available at: http://www.rponline.de/wirtschaft/news/unternehmen/Milliardenauftrag-fuerRheinmetall_aid_729059.html, accessed 6th July 2009.

Rheinmetall (2004), Leistungsstark: Puma, in: R Das Profil - Die Zeitung des Rheinmetall Konzerns, Vol. 5, 2004, pp. 1 - 14.

Rogers, E.W./Birmingham, R.P. (2004), A ten-year review of the vision of transforming the defense acquisition system, in: Defense Acquisition Review Journal, January-April, 2004, pp. 37- 61.

Royal Air Force Historic Society (2002), The Birth of Tornado, Oxford.

Royal United Services Institute (RUSI) (2009), Preparing for the leanere years, Future Defence Review Working Paper, No. 1, retrieved July 31, 2009, available at: http://www.rusi.org, accessed 3rd November 2011.

Schank, J.F. (2005), Options for reducing costs in the United Kingdom's future aircraft carrier (CVF) programme, RAND, Santa Monica, CA.

Scheibert, M. (1987), SPz Marder und seine Varianten Roland TH 301 TÜR u.a., Friedberg 1987. 
Schlotter, P. (1975), Rüstungspolitik in der Bundesrepublik Deutschland - Die Beispiele Starfighter und Phantom, Frankfurt a.M 1975.

Schmidt, H. (1979), "Tornado" Militär und Rüstungspolitik in der BRD, Frankfurt a. M.

Schwarz, K. (2003), Airbus Military A400M contract finally signed, fewer aircraft - higher price, in: Flug-Revue, Vol. 7, 2003, p. 14.

Selvanathan, E.A. (1990), Standard errors for Laspeyres and Paasche index numbers, in: Economic Letters, Vol. 35, 1991, pp. 35 - 38.

Siegel, I. H. (1941), The difference between the Paasche and the Laspeyres Index-Number Formulas, in: Journal of the American Statistical Association,Vol. 36, 1941, 215, pp. 343 350 .

Sollorz, J. (2006), Projekt Schützenpanzer Puma - Technisch wirtschaftliche Umsetzung, in: Wehrtechnischer Report, Vol. 3-4/2005, 2nd ed., 2006, pp. 11 - 14.

Stauch, G./Hofmann, A. (1994), Eurofighter zum Abschuss freigegeben, available at: http://www.focus.de/politik/deutschland/eurofighter-zum-abschussfreigegeben_aid_146230.html, update: 2nd April 1994.

Sutton, O. (1997), Finally: Green Light for Eurofighter, in: Interavia Business \& Technology, 52, pp. 19 - 23.

Tatham, P. and Worrell, D. (2010), Lean Thinking in an Uncertain Environment, The Implications for UK Defence Acquisition, in: International Journal of Defense Acquisition Management, Vol. 3, 2010, pp. 1 - 22.

Tavana, M. (2004), “Quest 123: a benchmarking system for technology assessment at NASA”, Benchmarking: An International Journal, Vol. 11, 2004, pp. 370 - 84.

Tavana, M./Bourgeois, B.S./Sodenkamp, M.A. (2009), Fuzzy multiple criteria base realignment and closure (BRAC) benchmarking system at the department of defense, in: Benchmarking: An International Journal, Vol. 16, 2009, 2, pp. 192 - 221.

Taylor, T. /Tatham, P. (2008), Five Key Challenges for the Management of UK Defence: An Agenda for Research?, in: International Journal of Defense Acquisition Management, Vol. 1,2008 , pp. 22 - 38.

Triantafillou, P. (2007), Benchmarking in the public sector: a critical conceptual framework, Public Administration, Vol. 85, 2007, pp. 829 - 846.

Unciatrends (2011), Inflation Entwicklung in Deutschland 1952 - 2010 (in\%), available at: http://www.unciatrends.com/inflation-entwicklung-historische-inflationsraten-deutschland, accessed 12th May 2011.

Vagnonoi, E./Maran, L. (2008), Public sector benchmarking: an application to italian health district activity plans, in: Benchmarking: An International Journal, Vol. 15, 2008, pp. 193 211.

Wache, S. (2003), F-40 Die Flugzeuge der Bundeswehr: Lockheed F-104F /TF-104G Starfighter, Buchholz 2003.

Weckbach-Mara, F. (2002), Der Kampf ums Geld, auf der Seite der Zeitung Welt, available at: http://www.welt.de/print-wams/article607756/Der_Kampf_ums_Geld.html, update: 6th Oktober 2002. 


\section{Acknowledgements}

We would like to express our gratitude to the reviewers and particularly to the editor, Professor Juha-Matti Lehtonen for their support. Their advice and comments helped to develop this paper. 